\title{
The Effect of Long - Irradiation of LED Lights on The Growth and Quality of Mustard Pakchoi Plants on Hydroponic Methods of Wick Systems
}

\author{
Ahmad Zainudin ${ }^{1)^{*}}$, M. Abror ${ }^{2)}$ \\ \{zainudinasr@yahoo.co.id ${ }^{1}$, abror@umsida.ac.id ${ }^{2}$ \}
}

Program Studi Agroteknologi, Fakultas Sains dan Teknologi, Universitas Muhammadiyah Sidoarjo

\begin{abstract}
This study aims to determine the effect of long-irradiation of LED lights on the growth and quality of mustard pakchoi plants on hydroponic methods of wick systems. The research was conducted for 2 months from June to July 2020 in Pekukuhan Village. Mojosari Regency. Mojokerto and Plant Physiology Laboratory, University of Muhammadiyah Sidoarjo. This study used a randomized block design and arranged in one factor, namely the length of exposure and the repetition of 5 times in order to obtain 25 experimental treatment units. The results showed that there was a significant effect of the leaf area variable on the LED lighting treatment at the age of 28 and 35 days with the highest average area $(45 \mathrm{~cm})$ at 12 hours of exposure time, while the wet weight variable showed a significant effect on the 8 hours irradiation time $(96.47 \mathrm{gr})$. Testing the chlorophyll content of mustard leaves produced the highest average total chlorophyll value $(29.50 \mathrm{mg} / \mathrm{l})$ and good antioxidant activity occurred in the treatment without LED lighting with the lowest value $(357,836 \mu \mathrm{g} / \mathrm{ml})$ because the lower of IC50 value, the better of antioxidants activity.
\end{abstract}

Keywords - LED lighting; Chlorophyll; Antioxidant

\begin{abstract}
Abstrak. Penelitian ini bertujuan untuk mengetahui pengaruh lama penyinaran lampu LED terhadap pertumbuhan dan kualitas tanaman sawi pakchoi (Brassica rapa L.) pada metode hidroponik sistem wick. Penelitian dilakukan selama 2 bulan pada bulan Juni sampai bulan Juli 2020 di Desa Pekukuhan kec . Mojosari kab. Mojokerto dan Laboratorium Fisiologi tumbuhan Universitas Muhammadiyah Sidoarjo. Penelitian ini menggunakan Rancangan Acak Kelompok $(R A K)$ disusun secara faktor tunggal yaitu lama penyinaran dan diulang sebanyak 5 kali sehingga didapat 25 unit perlakuan percobaan. Hasil penelitian menunjukkan pengaruh nyata terhadap variabel luas daun dan pada perlakuan penyinaran lampu LED pada umur 28 dan 35 hari dengan luas rata-rata tertinggi $(45 \mathrm{~cm})$ pada lama penyinaran $12 \mathrm{jam}$, sedangkan variabel berat basah menunjukkan pengaruh nyata pada lama penyinaran 8 jam sebesar (96.47 gr). Uji kandungan klorofil pada daun sawi pakchoi menghasilkan nilai rata-rata klorofil total tertinggi $(29.50 \mathrm{mg} / \mathrm{l})$ dan aktivitas antioksidan yang baik terjadi pada perlakuan tanpa adanya penyinaran lampu LED dengan nilai terendah sebesar $(357.836 \mu \mathrm{g} / \mathrm{ml})$ karena semakin rendah nilai IC $\mathrm{C}_{50}$ maka semakin baik aktivitas antioksidannya.
\end{abstract}

Kata Kunci - Lampu LED; Klorofil; Antioksidan

\section{Pendahuluan}

Gerakan pertanian perkotaaan dapat menjadi tulang punggung dalam meningkatkan kemandirian masyarakat terutama menjaga ketahanan pangan dalam skala rumah tangga. Sistem hidroponik dapat menjadi salah satu pilihan bertani untuk mengatasi keterbatasan lahan yang sempit diperkotaan [1]. Menurut [2], bercocok tanam tanpa menggunakan media tanah adalah merupakan keunggulan dari Hidroponik. Keterbatasan lahan merupakan ruang dan peluang untuk pengembangan hidroponik didaerah yang kepemilikannya sempit seperti diperkotaan dengan kondisi tanah yang kritis, hama dan penyakit yang tak terkendali, serta terbatasnya air irigasi. Tanaman yang dikembangkan dengan sistem ini juga membutuhkan sinar matahari untuk pertumbuhan dan berkembangan. Salah satu faktor terpenting dalam proses fotosintesis untuk menghasilkan energi sebagai bahan bakar pada pertumbuhan tanaman adalah sinar atau cahaya [3].

Kondisi cuaca di Indonesia yang mempunyai dua musim yaitu kemarau dan penghujan, khusus dimusim penghujan yang tinggi menjadi kendala petani konvensional sehingga mengakibatkan penurunan produksi, karena tanaman tidak mengalami proses fotosintesis secara maksimal. Untuk mengatasi berkurangnya cahaya matahari sebagai proses fotosintesis dapat dilakukan cara alternatif menggunakan lampu LED atau Growing Light. Hasil penelitian Kobayashi et.al. [4], menunjukkan bahwa masa panen selada dapat dipercepat dengan cara penambahan lampu LED. Lampu LED warna biru merangsang pertumbuhan vegetatif, sedangkan warna merah mempercepat proses pembungaan. Sedangkan pada penelitian [5], menunjukan bahwa pertumbuhan dan perkembangan tanaman selada akan menghasilkan banyak efek posistif apabila menggabungkan antara RBW (Red,Blue,White) LED. Warna lampu sangat berpengaruh pada pertumbuhan tanaman, karena pada dasarnya tanaman sangat membutuhkan cahaya yang lebih terang untuk menggantikan sinar matahari sebagai proses fotosintesis, maka penggunaan lampu yang berwarna putih mampu mempercepat pertumbuhan kangkung [6]. 
Sinar yang dihasilkan oleh lampu sangat berpengaruh pada pertumbuhan tanaman, oleh karena itu pemilihan daya sangatlah penting untuk proses fotosintesis bagi tanaman. Semakin besar nilai daya lampu, maka semakin besar pula panas dan terang yang dihasilkan oleh lampu dan hal tersebut akan mempengaruhi pertumbuhan tanaman. Sinar matahari yang berlebihan akan menyebabkan fotosintesis menjadi rendah dan jumlah klorofil sedikit begitu pula jika tanaman kekurangan cahaya. Lampu LED 20 watt memiliki panas dan sinar cahaya yang hampir sama pada lampu hemat energi 18 watt [7].

Jenis tanaman yang sering dikembangkan dengan sistem hidroponik antara lain sawi pakchoi yang disebut juga sawi china (Brassica rapa L.) Pakchoi memiliki nilai ekonomis tinggi dan komposisi gizi yang baik sehingga baik untuk asupan gizi masyarakat. Penelitian ini menggunakan teknologi hidroponik sistem wick yang disebut juga dengan sistem sumbu, menjadi pengembangan dari sistem sebelumnya yaitu water culture, dan sangat efektif dilahan yang sempit dipekarangan rumah terutama untuk tanaman sayuran karena muda dalam perawatan [8].

\section{METODE}

\section{A. Tempat dan waktu}

Penelitian dilakukan selama 2 bulan pada bulan Juni 2020 sampai bulan Juli 2020. Penelitian dilakukan di Desa Pekukuhan kec. Mojosari kab. Mojokerto.

\section{B. Bahan dan alat}

Bahan utama yang digunakan adalah benih sawi pakchoi, media tanam rockwol, air, nutrisi AB-mix, kabel. Alat yang digunakan adalah wadah penyemaian, bak plastik, Styrofoam, netpot, lampu LED, TDS meter, PH meter, timer, kain flannel, gunting, timbangan digital, meteran, kertas transparan, alat tulis, dan kamera.

\section{Rancangan penelitian}

Penelitian ini menggunakan Rancangan Acak Kelompok (RAK) disusun secara faktor tunggal yaitu lama penyinaran $(\mathrm{P})$ dan diulang sebanyak 5 kali.

Faktor:

- $\quad \mathrm{P} 0=$ Perlakuan Tanpa Penyinaran Lampu LED

- $\quad \mathrm{P} 1=$ Perlakuan Dengan Lama Penyinaran Selama 6 jam

- $\quad \mathrm{P} 2$ = Perlakuan Dengan Lama Penyinaran Selama 8 jam

- $\quad$ P3 = Perlakuan Dengan Lama Penyinaran Selama 10 jam

- $\quad$ P4 = Perlakuan Dengan Lama Penyinaran Selama 12 jam

Maka diperoleh denah penelitian dimana terdapat 5 perlakuan dan 3 ulangan sehingga terdapat 15 satuan percobaan sebagai berikut (Tabel. 1).

Tabel 1. Denah Penelitian

\begin{tabular}{lllll}
\hline Ulangan 1 & Ulangan 2 & Ulangan 3 & Ulangan 4 & Ulangan 5 \\
\hline $\mathrm{P} 4$ & $\mathrm{P} 2$ & $\mathrm{P}$ 1 & $\mathrm{P}$ 1 & $\mathrm{P} 3$ \\
\hline $\mathrm{P} 2$ & $\mathrm{P} 3$ & $\mathrm{P} 3$ & $\mathrm{P} 4$ & $\mathrm{P} 0$ \\
\hline $\mathrm{P} 3$ & $\mathrm{P} 4$ & $\mathrm{P} 0$ & $\mathrm{P} 2$ & $\mathrm{P} 4$ \\
\hline $\mathrm{P} 1$ & $\mathrm{P} 0$ & $\mathrm{P} 4$ & $\mathrm{P} 3$ & $\mathrm{P} 2$ \\
\hline $\mathrm{P} 0$ & $\mathrm{P} 1$ & $\mathrm{P} 2$ & $\mathrm{P} 0$ & $\mathrm{P} 1$ \\
\hline
\end{tabular}

Pada penelitian ini terdapat rancangan percobaan dengan persiapan instalasi Hidroponik dengan system wick dan peletakan lampu LED sesuai sketsa gambar berikut (Gambar 1). 


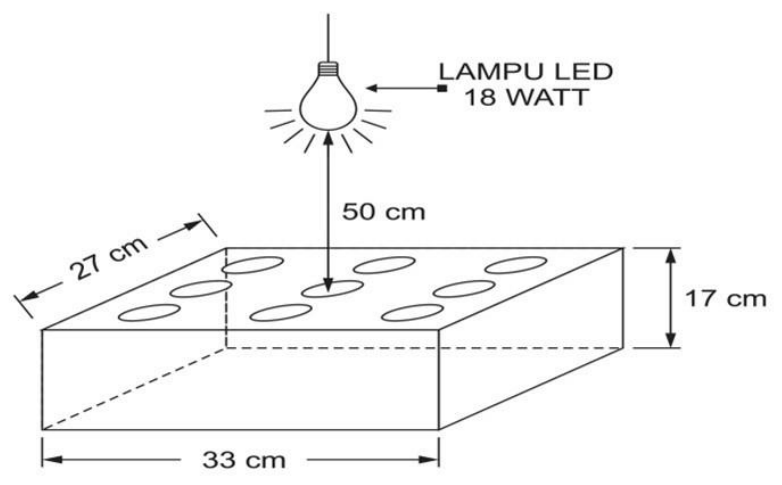

Gambar 1. Rancangan hidroponik sistem wick dengan menggunakan penyinaran lampu LED

\section{Pelaksanaan penelitian}

- Persiapan media tanam

Media tanam rockwol, nutrisi A/B Mix dan bibit sawi pakchoi didapatkan di toko pertanian. Pembuatan media tanam dengan menggunakan bak plastik. Kemudian styrofoam yang sudah diberi lubang sesuai dengan ukuran nettpot diletakkan diatas bak plastik. Lampu LED 20 watt diletakkan pada bagian tengah atas dengan jarak $50 \mathrm{~cm}$. Lampu yang telah dipasang kemudian diatur waktu lama penyinarannya dengan menggunakan timer.

- Pemindahan pada media tanam

Benih sawi pakchoi di semai menggunakan baki dengan media rockwool. Benih yang telah disemai tersebut dirawat sampai berumur 14 hari setelah semai dan berdaun 3-4 helai dipindah tanam ke instalasi, dan rockwool dipotong sesuai dengan ukuran netpot.

\section{- Pemberian Nutrisi}

Tahapan pemberian nutrisi Hidroponik AB Mix untuk tanaman sawi dari minggu pertama sampai minggu terakhir berbeda-beda. -7 :

Berikut ini tahapan pemberian nutrisi $\mathrm{AB}$ Mix dari minggu pertama sampai minggu terakhir dengan $\mathrm{PH}$ 6,3

1) Dosis Nutrisi Minggu 1 sebesar 500 PPM

2) Dosis Nutrisi Minggu 2 sebesar 700 PPM

3) Dosis Nutrisi Minggu 3 sebesar 900 PPM

4) Dosis Nutrisi Minggu 4-5 sebesar 1200 PPM

\section{- Perawatan}

Penambahan maupun penggantian air dan nutrisi AB Mix dilakukan jika keadaan air pada bak plastik berkurang atau bisa diukur dengan menggunakan TDS meter. Lampu LED dihidupkan bersama mulai pukul 17.00 WIB dan dimatikan sesuai dengan perlakuan.

\section{- Pengamatan}

Variabel yang diamati dalam percobaan ini adalah sebagai berikut :

1) Kandungan klorofil

Ditentukan dengan Uji Laboratorium dengan menggunakan alat Spektrofotometer Uv Vis.

2) Luas daun $(\mathrm{cm})$

Diukur dengan menggunakan aplikasi pengukur luas daun.

3) Berat basah per tanaman (gram)

Diukur dengan menggunakan Timbangan Digital.

4) Antioksidan

Ditentukan dengan Uji Laboratorium dengan menggunakan alat spektrofotometer Uv Vis

\section{E. Analisis data}

Analisis data menggunakan analisis ragam untuk mengetahui pengaruh lama penyinaran yang berbeda. Apabila didapatkan perbedaan yang nyata dilanjutkan uji BNJ $5 \%$.

\section{Hasil dan Pembahasan}

\section{A. Hasil pengamatan}

Luas daun

Hasil analisis ragam perhitungan luas daun menunjukan bahwa perlakuan lama penyinaran lampu LED terhadap luas daun sawi pakcoy dengan metode hidroponik sistem wick tidak berpengaruh nyata pada umur 7, 14, 21 HST. 
Procedia of Engineering and Life Science Vol.1 No. 1 March 2021

Seminar Nasional \& Call for Paper Fakultas Sains dan Teknologi (SENASAINS $1^{\text {st }}$ )

Universitas Muhammadiyah Sidoarjo

Namun, berpengaruh nyata pada umur 28 dan 35 HST (Lampira 1). Setelah dilakukan uji BNJ 5\% maka data selengkapnya disajikan pada tabel 2.

Tabel 2. Perlakuan lama penyinaran lampu LED terhadap luas daun pada umur 7-35 HST

\begin{tabular}{cccccccc}
\hline \multirow{2}{*}{ Perlakuan } & $\mathbf{7}$ & $\mathbf{1 4}$ & $\mathbf{2 1}$ & $\mathbf{2 8}$ & $\mathbf{3 5}$ & \\
\cline { 2 - 8 } & $\mathbf{7}$ & 18 & 21 & 24 & $\mathrm{a}$ & 22 & $\mathrm{a}$ \\
P0 & 12 & 20 & 20 & 24 & $\mathrm{a}$ & 26 & $\mathrm{ab}$ \\
P1 & 13 & 18 & 19 & 25 & $\mathrm{a}$ & 36 & $\mathrm{ab}$ \\
P2 & 11 & 19 & 18 & 25 & $\mathrm{a}$ & 32 & $\mathrm{ab}$ \\
P3 & 12 & 16 & 22 & 33 & $\mathrm{a}$ & 45 & $\mathrm{~b}$ \\
P4 & 13 & tn & tn & $\mathbf{9 . 2 5}$ & & $\mathbf{1 9 . 1 1}$ &
\end{tabular}

Keterangan: Angka-angka yang di dampingi oleh huruf kecil yang berbeda pada kolom menunjukkan berpengaruh nyata pada uji BNJ 5\%; tn : berbeda tidak nyata (tn)

Hasil uji BNJ 5\% menunjukkan bahwa perlakuan lama penyinaran lampu LED tidak menunjukkan pengaruh nyata pada saat umur 7, 14, dan 21 HST pada semua perlakuan. Namun justru menunjukkan pengaruh pada umur 28 dan 35 HST dengan rerata tertinggi sebesar $45 \mathrm{~cm}^{2}$ pada perlakuan lama penyinaran selama 12 jam (P4). Rerata pertumbuhan luas daun pada setiap perlakuan perminggu tersaji pada Gambar 2.

Pertumbuhan luas daun dapat dipengaruhi oleh beberapa faktor lingkungan, seperti nutrisi dan system pengairan yang menunjang bagi pertumbuhan luas daun. Pertumbuhan luas daun akan berhenti apabila sudah mencapai batas maksimal, yang artinya secara fisiologis daun mempunyai pertumbuhan terbatas dan tidak terus menerus bertambah bila sudah mencapai bentuk dan ukuran lebar.

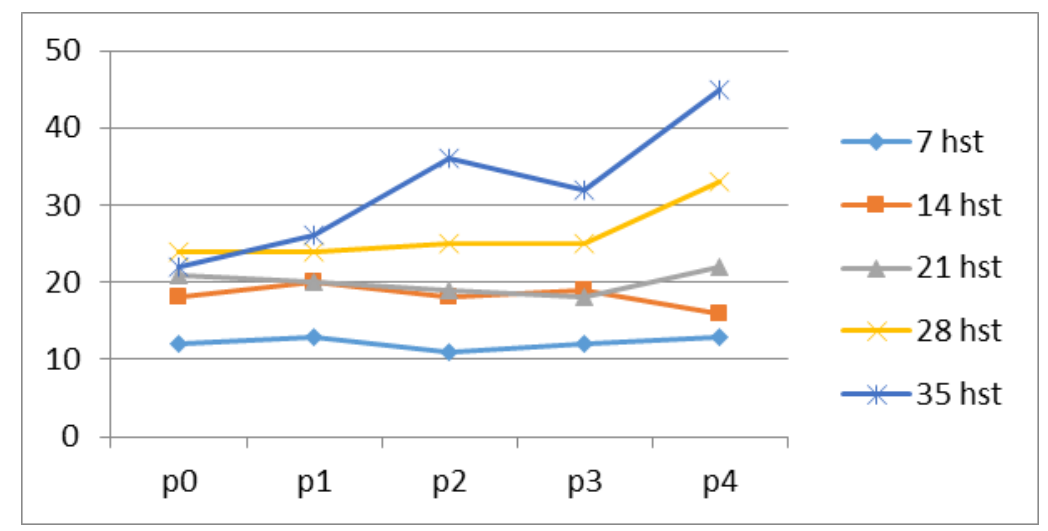

Gambar 2. Grafik perkembangan luas daun akibat perlakuan lama penyinaran lampu LED dengan metode hidroponik sistem wick

Berat Basah per tanaman ( $g r$ )

Hasil dari analisis ragam menunjukkan bahwa perlakuan lama penyinaran lampu LED terhadap berat basah sawi pakcoy dengan metode hidroponik sistem wick menunjukkan berpengaruh nyata (Lampiran 2). Setelah dilakukan uji BNJ 5\% maka data selangkapnya disajikan pada tabel 3.

Tabel 3. Perlakuan lama penyinaran lampu LED terhadap berat basah per tanaman pada umur 7-35 HST

\begin{tabular}{cc}
\hline Perlakuan & Berat Basah per Tanaman $($ gr) \\
\hline P0 & $95.20 \mathrm{ab}$ \\
P1 & $80.80 \mathrm{ab}$ \\
P2 & $96.47 \mathrm{~b}$ \\
P3 & $75.53 \mathrm{a}$ \\
P4 & $78.13 \mathrm{ab}$ \\
\hline BNJ 5\% & $\mathbf{1 9 . 9 9}$ \\
\hline
\end{tabular}

Keterangan : Angka-angka yang di dampingi oleh huruf kecil yang berbeda pada kolom menunjukkan berpengaruh nyata pada uji BNJ 5\% 
Hasil uji BNJ 5\%pada pengamatan berat basah tanaman sawi pakcoy menunjukkan hasil berat basah pertanaman paling berat pada perlakuan dengan lama penyinaran 8 jam (P2) yaitu dengan rata-rata berat basah (96.47 gr) dan rata-rata berat tanaman terendah (75.53 gr). Sehingga perlakuan P2 penyinaran lampu LED menunjukkan pengaruh nyata. Hal ini dapat dikatakan bahwa lama penyinaran yang cukup maka semakin intensif proses fotosintesis berlangsung sehingga hasil yang diperoleh semakin tinggi. Hasil dari proses fotosintesis akan ditranslokasikan keseluruh jaringan tanaman melalui floem yang kemudian energi hasil dari proses fotosintesis dipergunakan oleh tanaman untuk mengaktifkan pertumbuhan tunas, daun, dan batang. Hasil rata-rata pengaruh lama penyinaran lampu LED mulai 7-35 HST tersaji pada Gambar 3.

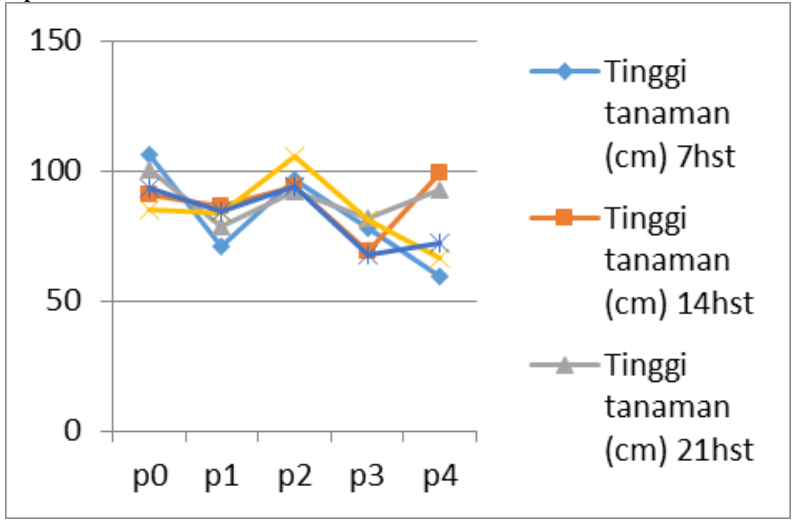

Gambar 3. Grafik rata-rata berat basah sawi pakchoi akibat perlakuan lama penyinaran lampu LED dengan metode hidroponik sistem wick

\section{Hasil Uji Antioksidan}

Pengujian aktivitas antioksidan dengan menggunakan metode penangkapan radikal bebas DPPH. Perubahan warna dari ungu menjadi kekuningan setelah selama 30 menit di inkubasi dan diukur absorbansinya dengan panjang gelombang $517 \mathrm{~nm}$ dengan menggunakan spektrofotometer UV-VIS (lampiran 3). Perubahan warna ini menunjukkan efisiensi radikal bebas. Untuk melihat efektifitas antioksidan maka dilanjutkan dengan uji $\mathrm{IC}_{50}$, ratarata nilai $\mathrm{IC}_{50}$ pada setiap perlakuan tersaji pada tabel 4.

Tabel 4. rata-rata nilai $\mathrm{IC}_{50}$ pada setiap perlakuan

\begin{tabular}{cc}
\hline Perlakuan & Nilai $\mathbf{I C}_{\boldsymbol{5 0}}(\boldsymbol{\mu} \mathbf{g} / \mathbf{m l})$ \\
\hline P0 & 357.836 \\
P1 & 772.206 \\
P2 & 719.575 \\
P3 & 497.945 \\
P4 & 401.813
\end{tabular}

Berdasarkan perhitungan nilai $\mathrm{IC}_{50}$ maka diperoleh nilai paling rendah yaitu pada rata-rata perlakuan $\mathrm{P} 0$ dengan tanpa penyinaran lampu LED sebesar $357.836 \mu \mathrm{g} / \mathrm{ml}$. Ini berarti ekstrak sawi pada perlakuan P0 mempunyai aktifitas antioksidan terbaik karena mempunyai nilai $\mathrm{IC}_{50}$ paling rendah. Hal ini menunjukkan aktivitas antioksidan semakin kecil nilai $\mathrm{IC}_{50}$ maka senyawa tersebut mempunyai keefektifan sebagai penangkap radikal yang lebih baik.

Hasil Uji Klorofil

Klorofil merupakan pigmen yang berperan dalam proses fotosintesis pada semua tumbuhan hijau. Klorofil paling penting dan merupakan dasar proses kehidupan tumbuhan dengan merubah energi cahaya menjadi energi kimia sehingga klorofil merupakan zat yang paling banyak didistribusikan tumbuhan. Setiap tanaman terutama sayuran daun memiliki jumlah klorofil yang berbeda-beda, karena beberapa faktor seperti perlakuan yang diberikan.

Hasil pengamatan terhadap pengukuran kadar klorofil pada sawi pakchoi dengan perlakuan lama penyinaran lampu LED, menunjukkan bahwa terdapat adanya perbedaan jumlah klorofil yang terkandung pada bagian daun sawi pakchoi pada setiap perlakuan. Rata-rata hasil pengamatan terhadap kandungan klorofil pada daun sawi pakchoi dengan parameter kandungan klorofil, yaitu klorofil total tersaji pada tabel 5. 
Procedia of Engineering and Life Science Vol.1 No. 1 March 2021

Seminar Nasional \& Call for Paper Fakultas Sains dan Teknologi (SENASAINS $1^{\text {st }}$ )

Universitas Muhammadiyah Sidoarjo

Tabel 5. Rata-rata kandungan klorofil total pada daun tanaman sawi pakchoi

\begin{tabular}{|c|c|c|c|c|c|c|c|}
\hline \multirow[t]{2}{*}{ Perlakuan } & \multicolumn{5}{|c|}{ Ulangan } & \multirow[t]{2}{*}{ Jumlah } & \multirow[t]{2}{*}{ Rata-rata } \\
\hline & 1 & 2 & 3 & 4 & 5 & & \\
\hline $\mathrm{PO}$ & 8.19 & 9.89 & 29.99 & 33.78 & 37.77 & 119.59 & 23.92 \\
\hline $\mathrm{P} 1$ & 7.50 & 39.85 & 7.61 & 20.16 & 7.74 & 82.85 & 16.57 \\
\hline $\mathrm{P} 2$ & 9.17 & 17.84 & 24.28 & 12.61 & 16.85 & 80.75 & 16.15 \\
\hline P3 & 11.39 & 21.02 & 13.93 & 31.88 & 21.99 & 100.21 & 20.04 \\
\hline $\mathrm{P} 4$ & 31.27 & 31.25 & 24.50 & 23.76 & 36.71 & 147.49 & 29.50 \\
\hline Total & 67.53 & 119.81 & 100.32 & 122.18 & 121.06 & 530.90 & 106.18 \\
\hline
\end{tabular}

Tabel 5 menunjukkan rata-rata kandungan klorofil total (lampiran 4) pada setiap perlakuan pada bagian daun sawi pakchoi memperoleh hasil yang berbeda. Jumlah rata-rata klorofil total pada bagian daun tertinggi pada perlakuan dengan lama penyinaran lampu LED selama 12 jam (P4), yaitu dengan nilai rata-rata $29.50 \mathrm{mg} / \mathrm{l}$ dan nilai rata-rata terendah $16.15 \mathrm{mg} / \mathrm{l}$ dengan perlakuan lama penyinaran lampu LED selama 8 jam (P2). Data tersebut tersaji pada gambar 4.

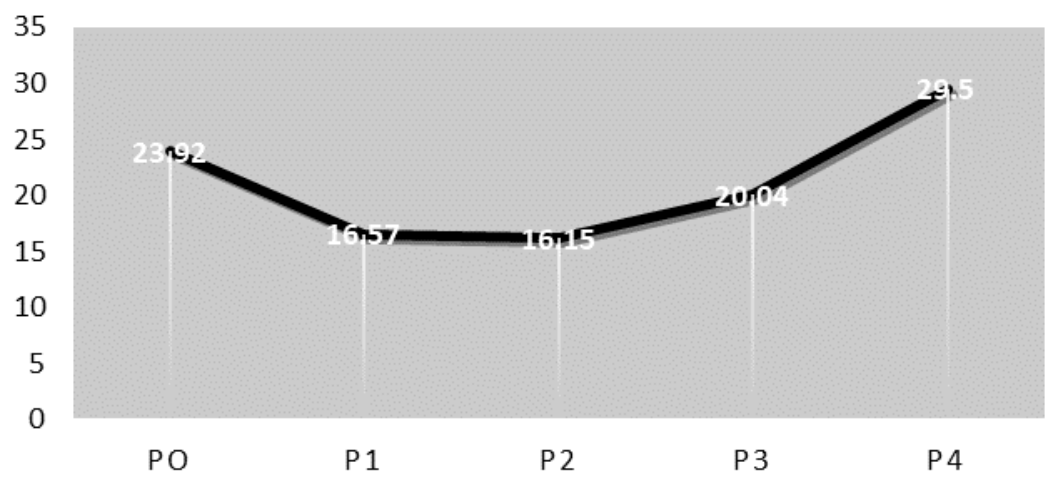

Gambar 4. Grafik Rata-rata Jumlah Klorofil Total

Berdasarkan (Gambar 4) menunjukkan rata-rata jumlah klorofil total pada setiap perlakuan dengan rata-rata tertinggi pada perlakuan P4 (29.50 mg/l) dan terendah pada perlakuan P2 (16.15mg/l). Untuk mengetahui perbedaan terhadap kandungan klorofil total pada daun sawi pakchoi maka dilakukan analisis dengan uji BNJ 5\%. Hasil pengujian menunjukkan pengaruh tidak nyata. Hal tersebut disajikan pada tabel 6 .

Tabel 6. Analisis varians rata-rata kandungan klorofil total pada daun sawi pakchoi

\begin{tabular}{c|ccccccc}
\hline SK & DB & JK & KT & $\begin{array}{c}\text { F } \\
\text { HITUNG }\end{array}$ & & F 0.05 & F 0.01 \\
\hline KELOMPOK & 4 & 438.30 & 109.58 & 1.08 & tn & 3.07 & 4.77 \\
PERLAKUAN & 4 & 622.57 & 155.64 & 1.53 & tn & 3.06 & 4.77 \\
GALAT & 16 & 1631.70 & 101.98 & & & & \\
\hline TOTAL & $\mathbf{2 4}$ & $\mathbf{2 6 9 2 . 5 7}$ & & & & & \\
\hline
\end{tabular}

Keterangan : tn : berbeda tidak nyata (tn)

Berdasarkan hasil perhitungan BNJ 5\% terhadap rata-rata total jumlah kandungan klorofil pada daun sawi pakchoi menunjukkan tidak ada perbedaan yang nyata dengan nilai $\mathrm{F}$ hitung $(1,53)<\mathrm{F}$ tabel $0,05(3,06)$.

\section{B. Pembahasan}

Dari data hasil penelitian Pengaruh Lama Penyinaran Lampu LED Terhadap Pertumbuhan dan Kualitas Tanaman Sawi Pakchoi (Brassica rapa L.) Pada Metode Hidroponik Sistem Wick berpengaruh nyata pada luas daun pada umur 28 HST dan 35 HST. Pada variabel pengamatan luas daun menunjukkan bahwa penyinaran lampu LED dengan lama penyinaran 12 jam (P4) menghasilkan rata-rata luas daun tertinggi $\left(45 \mathrm{~cm}^{2}\right)$. Tanaman sawi pakchoi 
tumbuh dengan baik pada suhu penanaman rata-rata $15-30^{\circ} \mathrm{C}$ serta mendapatkan penyinaran yang optimal antara 1013 jam per hari dan kelembapan 60-100\% [9].

Penggunaan metode penanaman secara hidroponik dengan wick system juga berpengaruh terhadap pertumbuhan dan kualitas sawi pakchoi. System penanaman ini mampu mengontrol kebutuhan air tanaman supaya tetap lembab dan dengan penggunaan kain flannel sebagai sumbu agar memudahkan perakaran untuk mencapai air sehingga mencegah tanaman tergenang dimana pada wadah volume air yang dibutuhkan sekitar seperempat bagian. Pertumbuhan sawi pakchoi memerlukan kondisi udara yang lembab dan sejuk untuk mempercepat waktu tumbuh, namun sawi pakchoi tidak menyukai kondisi yang terlalu tergenang. Apabila kondisi perakaran tergenang atau volume air menyentuh hingga daerah perbatangan, maka tanaman sawi pakchoi akan membusuk [10].

Berat basah tanaman sawi pakchoi (Brassica rapa L.) merupakan keseluruhan jumlah berat tanaman secara utuh dari akar hingga daun yang menunjukkan adanya aktivitas metabolic tanaman dimana semakin tinggi hasil komponen tumbuhan maka akan diikuti dengan berat basah tanaman yang juga meningkat. Pada data penelitian lama penyinaran lampu LED dengan metode hidroponik system wick ini menunjukkan pengaruh nyata pada 8 jam lama penyinaran. Dengan kebutuhan air yang tercukupi dan lama penyinaran yang tepat membuat kandungan air pada tanaman tinggi, selain itu dengan cara pemanenan beserta perakarannya membuat tanaman sawi pakchoi tetap segar. Bila volume air yang terlalu tinggi akan menyebabkan kebusukan maka kekurangan air akan membuat sawi pakchoi mengalami pertumbuhan abnormal, kelayuan, dan kematian.

Menurut Anjeliza [11] sekitar $80 \%$ hingga $85 \%$ dari berat basah herba atau tumbuhan tidak berkayu ialah air, dan Sebagian besar pertumbuhan tumbuhan yaitu dengan cara mengakumulasi air didalam vakuola. Air bagi tumbuhan berperan sebagai nutrient karena air penyedia Sebagian besar atom hydrogen dan atom oksigen yang digabungkan dalam senyawa organic pada peristiwa fotosintesis. Pada umumnya air yang diserap oleh tumbuhan 90\% akan hilang melalui proses transpirasi dan air yang dipertahankan berfungsi sebagai bahan pelarut yang bertugas mempertahankan bentuk jaringan yang lunak dengan menjaga sel tetap turgid dan memungkinkan terjadinya pemanjangan sel. Kemampuan tumbuhan dalam menyerap air terletak pada akarnya, kondisi akar yang baik akan mendukung proses penyerapan air yang optimal.

Antioksidan berfungsi untuk mencegah terjadinya oksidasi atau menetralkan suatu senyawa yang teroksidasi dengan mentransfer electron atau hydrogen. Antioksidan merupakan bahan tambahan atau pelengkap yang berguna untuk melindungi komponen makanan yang bersifat tidak jenuh seperti minyak dan lemak. Antioksidan terdapat dua macam jenis yaitu antioksidan sintesa yang diperoleh dari hasil sintesa reaksi kimia dan antioksidan alami yang merupakan hasil dari ektraksi bahan alami seperti sayuran [12].

Menurut Pontoh [13] mengukur kadar antioksidan menggunakan metode peredaman radikal bebas dengan DPPH (1,1-difenil-2-pikrilhidrazil), kemudian sebanyak 0,5 ml ekstrak methanol dan air ditambah larutan DPPH sebanyak $2 \mathrm{ml}$ dan divortex selama dua menit. Selanjutnya menjelang 30 menit waktu inkubasi dilakukan pengukuran absorbansi dengan Panjang gelombang $517 \mathrm{~nm}$ menggunakan spektrofotometer. Tingkat kekuatan antioksidan dengan metode DPPH diukur berdasarkan nilai $\mathrm{IC}_{50}$ dimana diperoleh intensitas sangat kuat $(<50 \mu \mathrm{g} / \mathrm{ml})$, $\mathrm{kuat}(50$ $100 \mu \mathrm{g} / \mathrm{ml})$, sedang $(101-150 \mu \mathrm{g} / \mathrm{ml})$, dan lemah $(>150 \mu \mathrm{g} / \mathrm{ml})$. Berdasarkan nilai tersebut dapat disimpulkan semakin rendah nilai antioksidan maka kekuatan antioksidan semakin kuat.

Pada penelitian ini diperoleh data nilai kadar antioksidan berdasarkan $\mathrm{IC}_{50}$ pada perlakuan tanpa penyinaran lampu LED memiliki nilai terendah $(357.836 \mu \mathrm{g} / \mathrm{ml})$ yang berarti memiliki antioksidan lemah. Pada penelitian ini menggunakan sampel segar karena apabila menggunakan sampel kering dikhawatirkan zat yang berpotensi sebagai antioksidan mengalami kerusakan karena proses pengeringan. Akan tetapi, baik menggunakan sampel segar maupun kering apabila terlalu lama disimpan maka terdapat kemungkinan zat yang terkandung didalamnya akan rusak atau hilang. Lina [14] menyatakan bahwa terjadi penurunan aktivitas antioksidan alga coklat akibat teroksidasi folifenol florotanin selama masa penyimpanan.

Kandungan klorofil didalam sayuran daun merupakan salah satu kriteria penting untuk menentukan kandungan zat gizi sayuran daun. Klorofil juga diketahui berperan sebagai antioksidan bagi tubuh. Jumlah rata-rata kandungan klorofil total daun tertinggi terdapat pada perlakuan 12 jam lama penyinaran lampu LED yaitu dengan nilai rata-rata $29,50 \mathrm{mg} / \mathrm{l}$. Pada lama penyinara 12 jam tanaman sawi pakchoi memiliki kemampuan menangkap radiasi cahaya lebih efisien dan optimal dibandingkan dengan perlakuan lainnya. Distribusi klorofil pada daun berbeda-beda, seperti warna daun daun luas daun. Semakin hijau warna daun maka semakin tinggi kandungan klorofilnya, begitupun semakin luas permukaan daun maka semakin baik dalam menangkap radiasi cahaya sehingga proses fotosintesis lebih optimal [15].

Kandungan klorofil pada daun tanaman akan berpengaruh pada reaksi fotosintesis. Reaksi fotosintesis tidak akan maksimal apabila kadar klorofil yang terkandung terlalu sedikit. Ketika reaksi fotosintsesis tidak maksimal, senyawa karbohidrat yang dihasilkan juga tidak bisa maksimal. Pada tumbuhan karbohidrat terdapat sebagai selulosa, yaitu senyawa yang membentuk dinding sel tumbuhan [16]. Selain berperan bagi tumbuhan itu sendiri, klorofil juga berperan untuk Kesehatan tubuh.

Sawi pakchoi (Brassica rapa L.) merupakan sayuran dari keluarga Brassicaciae yang memiliki kandungan fitokimia bioaktif yang sangat baik dan mampu mengurangi risiko penyakit kronis yang berhubungan dengan usia, seperti kardioviskular, kanker, dan penyakit degenerative lainnya. Hal ini berkaitan dengan kemampuan antioksidan 
dari kandungan senyawa sayuran sawi. Dos reis [17] menyatakan bahwa tanaman sawi memiliki beberapa senyawa seperti klorofil, karotenoid, flavonoid, dan fenolik. Klorofil yang terkandung dalam sawi sangat potensial untuk dikembangkan sebagai suplemen dalam penanganan penyakit kanker dan penyakit degenerative. Ketersediaan klorif yang tinggi di alam dan khasiatnya secara biologis menjadi peluang untuk dijadikan sebagai pangan fungsional dan bahan suplemen pangan.

\section{KESIMPULAN}

Pengaruh lama penyinaran lampu LED pada pertumbuhan dan kualitas tanaman sawi pakchoi (Brassica rapa L.) dengan metode hidroponik system wick menunjukkan hasil yang berbeda. Pada perlakuan lama penyinaran lampu LED selama 12 jam dengan daya 18watt menunjukkan hasil yang optimal pada luas daun tanaman sawi pakchoi dan dengan kandungan klorofil pada daun tertinggi. Sedangkan aktivitas antioksidan paling baik yaitu dengan tanpa adanya perlakuan penyinaran lampu LED dan hanya menggunakan sinar matahari langsung.

\section{UCAPAN TERIMA KASIH}

1) Bapak Dr. Hidayatulloh, M.Si., selaku Rektor Universitas Muhammadiyah Sidoarjo

2) Bapak Dr. Hindarto, S.Kom., MT. selaku Dekan Fakultas Sains dan Teknologi Universitas Muhammadiyah Sidoarjo.

3) Bapak M. Abror, SP., MM. selaku Ketua Jurusan Agroteknologi, Fakultas Sains dan Teknologi Universitas Muhammadiyah Sidoarjo.

4) Bapak M. Abror, SP., MM. selaku Dosen Pembimbing

5) Ayah dan Ibu yang tanpa lelah memberikan dukungan dan do'a yang tak tergantikan

6) Teman-teman agroteknologi dan THP yang selalu memberikan bantuan dan semangat

\section{REFERENSI}

[1] Santoso dan Widya . (2014). Gerakan Pertanian Perkotaan Dalam Mendukung Kemandirian Masyarakat Di Kota Surabaya. Surabaya: Institut Teknologi Sepuluh Nopember.

[2] Wibowo, S., \& Asriyanti, S. A. (2013). Aplikasi Hidroponik NFT pada Budidaya Pakcoy (Brassica rapa chinensis). Jurnal Penelitian Pertanian Terapan, 13.

[3] Lingga, P. 1999. Hidroponik Bercocok Tanam Tanpa Tanah. Penebar Swadaya. Jakarta. 99 hal.

[4] Kobayashi, K., T. Amore., and M. Lazaro. 2013. Light- Emitting Diodes (LEDs) for Miniature Hydroponic Lettuce. Optics and Photonics Journal (3): 7477.

[5] Lin, K.H., M.Y. Huang., W.D. Huang., M.H. Hsu., Z.W. Yang., and C.M. Yang. 2013. The Effects of Red, Blue, and White Light-Emitting Diodes on the Growth, Development, and Edible Quality of Hydroponically Grown Lettuce (Lactuca sativa L. var. capitata). Scientia Horticulturae 150: 86- 91.

[6] Acero. (2013). Pengaruh Warna Lampu LED Terhadap Pertumbuhan Tanaman Krisan. Skripsi. Jurusan Teknik Elektro Fakultas Teknologi Industri Institut Sains dan Teknologi AKPRIND: Yogyakarta.

[7] Mukhlis. B. 2011. Penghematan Energi Melalui Penggantian Lampu Penerangan di Lingkungan UNTAD. Jurnal Ilmiah Foristek. Vol.1, No.2: 1-7.

[8] Asmana MS., Sirajuddin HA., Guyup MDP. 2017. Analisis Keseragaman Aspek Fertigasi Pada Desain Sistem Hidroponik Dengan Perlakuan Kemiringan Talang. Jurnal Ilmiah Rekayasa Pertanian dan Biosistem. Vol.5 No.1

[9] Lestari, G., 2009. Berkebun Sayuran Hidroponik di Rumah, Prima Info Sarana, Jakarta.

[10] Haryanto, W., T. Suhartini, dan E. Rahayu. 2007. Teknik Penanaman Sawi dan Selada Secara Hidroponik. Jakarta : Penebar Swadaya.

[11] Anjeliza, R. Y. (2013). Pertumbuhan dan Produksi Tanaman Sawi Hijau (Brassica juncea L.) Pada Berbagai Desain Hidroponik. Makassar: Universitas Hasanuddin.

[12] Sari A. N., 2016, Berbagai Tanaman Rempah Sebagai Sumber Antioksidan Alami, Journal of Islamic Science and Technology, 2 (2)

[13] Pontoh F. W., Grace Sanger, Bertie E. Kaseger, Djuhria Wonggo , Roike I. Montolalu , Lena J. amongilala , Daisy Makapedua, Kandungan Fitokimia, Kadar Total Fenol Dan Aktivitas Ntioksidan Ekstrak Rumput Laut (Halymenia durvillae). Jurnal Media Teknologi Hasil Perikanan, 7 (3).

[14] Lina, 2008, Uji Aktivitas Penangkapan Radikal Hidroksil Oleh Fraksi Etil Asetat Ekstrak Metanolik Alga Coklat (Sargassum hystrix v. buxifolium (Chauvin) J. Agardh) Dengan Metode Deoksiribosa, Skripsi, Fakultas Farmasi, Universitas Sanata Dharma.

[15] Dewi R, Morfologi Tumbuhan, (Jakarta: Erlangga, 2013), hal. 2

[16] Yohanis, N. (2009). Biokimia: Struktur dan Fungsi Biomolekul. Yogyakarta: Graha Ilmu. 
Procedia of Engineering and Life Science Vol.1 No. 1 March 2021

Seminar Nasional \& Call for Paper Fakultas Sains dan Teknologi (SENASAINS 1st)

Universitas Muhammadiyah Sidoarjo

[17] Dos Reis, L. C. R.; de Oliveira, V. R.; Hagen, M. E. K.; Jablonski, A.; Flôres, S. H.; de Oliveira Rios, A., Carotenoids, flavonoids, chlorophylls, phenolic compounds and antioxidant activity in fresh and cooked broccoli (Brassica oleracea var. Avenger) and cauliflower (Brassica oleracea var. Alphina F1). LWTFood Science and Technology 2015, 63, (1), 177-183. 